\title{
Politic of Law on Judicial Review of Local Government Regulation in Indonesia
}

\author{
R.A Rini Anggraini ${ }^{1} \quad$ Widodo Ekatjahjana $^{2} \quad$ Dominikus Rato $^{2} \quad$ Aries Harianto $^{3}$ \\ 1.Doctorate Students at Faculty of Law, University of Jember \\ 2.Professor and Lecturer at Faculty of Law, University of Jember \\ 3.Doctor and Lecturer at the faculty of Law, University of Jember
}

\begin{abstract}
The debate over the enactment of the judicial review of local governmnet regulation has became a separate question in this era of regional autonomy. Considering that local governmnet regulations are the product of regional heads and House of Representatives (DPRDs) in an autonomous region, while one of the positive effects of developing the idea of regional autonomy is the strengthening of the existence of local regulations as regional legislative products that allows the development of all the potential characteristics of the region to get a clear juridical protection. The local governmnet Regulation (called as Perda in Indonesia) as Local Wet which has a prototype, that is congruent with Law (Wet) at the central level. Viewed from the scope of the material content, way of formulation, its formulation and constitution, its position in the order and its form as norm of law as determined in the Constitutional Law of the Formation of Constitutional Regulations, the Local governmnet Regulation is an independent product of law.
\end{abstract}

Keywords: local governmnet regulation, Judicial review, Constitutional Law

DOI: $10.7176 / \mathrm{JLPG} / 98-20$

Publication date:June 30th 2020

\section{Introduction}

The Local government Regulation (PERDA) is a statutory regulation formed by the House of the Representatives (DPRD) with the joint agreement of the Regional Head Article 1 number 8 of Law Number 12 of 2011. Through the second amendment to the 1945 Constitution of the Republic of Indonesia, the local government Regulation has its constitutional basis in the constitution whose existence is used to carry out autonomy and co-administration tasks of the Article 18 paragraph (6) of the 1945 Constitution of the Republic of Indonesia. Furthermore, the Article 14 of Law Number 12 of 2011 outlines that the contents of the Local governmnet Regulation are all material content in the framework of the implementation of autonomy and assistance tasks; accommodation on the special conditions of the area; the elaboration of the higher Statutory Regulations. ${ }^{1}$

The trial of local government Regulation s conducted by the government is not fully accepted by the regions, and many regions have objected it. The debate over the enactment of the cancellation of the Local government Regulation is a separate question in the era of regional autonomy; considering that the Local government Regulation is the product of the Regional Head and the Regional Parliament in an autonomous region while one of the positive effects of developing the idea of regional autonomy is the strengthening of the Local government Regulation as a regional legislative product that allows the development of regional's potential distinctions to have a clear juridical warranty.

According to Maria Farida Indrati ${ }^{2}$, the trial of local government Regulation is not conducted by the Supreme Court. According to the Law expert, it is related to the provisions of the Article 251 Paragraph (1) and Paragraph (2) of Law No.23 of 2014 concerning Regional Government, where the authority to examine and cancel a Local government Regulation only rests with the Central Government ${ }^{3}$ if the regulation contradicts to the higher laws, public interest and decency. It means that the responsible agent in the cancellation of Local government Regulation based on the constitution No. 23 of 2014 is the President itself whose implementation is carried out by the governor through Governor's Decree on the Cancellation of Local government Regulation and the Decree of the Ministry of Home Affairs for provincial regulation.

Since Regional Autonomy was rolled out, number of local government Regulation s have been formed by the Regional Government both at the Provincial and Regency/City. The data obtained from the Ministry of Finance about the Monitoring of Local government Regulation s on Regional Taxes and Regional Levies from 2001 to 27 November 2010, have indicated that the Local government Regulation received and evaluated with 9,408 regulations. The local regulation still deserved 4,523. The Minister of Finance was given recommendation to revise and cancel the 4,885 regulations. The number of Provincial Regencies, Regencies/Cities canceled by Decree of the Minister of Home Affairs from 2002 to 2009 was 1,878. The number of Local government Regulation in the

\footnotetext{
${ }^{1}$ The constitution of the Republic of Indonesia No. 12 year 2011 on the Regulation of Constitution.

${ }^{2}$ Maria Farida Indrati Soeprapto, Ilmu Perundang-undangan; Dasar-dasar dan Pembentukannya, (Jakarta: Kanisius, 1998), p. 32

${ }^{3}$ The Central Government is the President of the Republic of Indonesia that hold the power of state's government assisted by Vice of President and his ministers as mandated in the 1945 Constitution.
} 
level of Province and Regency/City terminated by the Minister of Home Affairs's clarification letter from January to October 2010 was 329 (2,678 processes of cancelling $)^{1}$.

The expert on Constitutional Law, Sri Soementri explained that there are various ways to revoke the law, because there are several parties who have the right to test the law. The right of judicial review is carried out not only by the Supreme Court, but also by the government, the President, and the Ministry of Home Affairs ${ }^{2}$. In contrast, according to Jimly Asshiddiqie the Local government Regulation as a work of the Regional Head and Regional Representative Council (DPRD) cannot be canceled by a unilateral decision from the central government ${ }^{3}$.

The regulation on Local government Regulation trial carried out by the government is philosophically an indication of the deviation on the function and purpose of law which negates the principle of democracy. On the other hand, the mechanism of Local government Regulation is also contrary to the constitution. Thus, as regulated in Law Number 23 of 2014 concerning regional governance in the normative level, this evidence is a form of legal uncertainty which contains the inconsistency of power distribution between executive, legislative and judiciary.

Based on the description, this study analyzes (1) whether or not the test/trial of the Local government Regulation by the government is not contrary to the principles of democracy that gives a freedom and independence for autonomous regions in regulating its management; and (2) whether or not the executive review after the decision of the Constitutional Court has met the national political law

\section{Research Method}

This study is a normative and doctrinal legal research. Normative is used due to the distinctive character of legal science that lies in the method of research which is normative. ${ }^{4}$ Doctrinal research is used to analyze the principles of law, legal literature, expert opinion (doctrine). ${ }^{5}$ In this study, there are 5 (five) approaches applied, are : (a) the statute approach; (b) the conceptual approach; (c) case approach; (d) the comparative approach and (d) a philosophical approach.

\section{Results and Discussion}

\subsection{Judicial Review of Local Government Regulation by the Government in the Principles of Democracy that Gives the Autonomous Region Freedom and Independence}

The implementation of regional government based on decentralization has resulted a regional autonomy, and the exercise of the authority of general government affairs is granted by the central government, so that regional government has initiatives and creative based on the regional potential they had in realizing regional democratization. According to Joeniarto, regional government eventually shows the synergy with the central government. The authority of the central government includes all regional governances, while the authority of regional government only covers a part of the state territory. Therefore, local government is distinguished into two different characteristics, namely local administrative government (local state government) and local autonomous government ${ }^{6}$.

Previewing the implementation of state government based on democracy, regional government is a subordinate of the state government which carries out democratic governance. Democratic regional government is based on people's welfare, equality, community participation and universalism. According to Indonesian political experts, Afan Gaffar (in Juanda $\mathrm{H})^{7}$, stated that democracy contains the following elements:

(1) The Implementation of power of the public;

(2) Implementing power with high responsibility;

(3) Directly and indirectly formulated;

(4) The rotation of power of a group;

(5) The existence of election process; and

(6) The existence of freedom as human rights (HAM).

Juanda provides elements of democracy, namely: first, there is power for the people to participate in determining the direction and their own interests in the administration of government; second, there is freedom which is responsible for determining their rights; third, competitive elections; fourth, the existence of democratic legal instruments and strict non-discriminatory law enforcement; fifth, there is a fairness and honest supervision ${ }^{8}$.

The principles of democracy in the implementation of regional government in regional autonomy are based on the principle of people's sovereignty and the principle of representative deliberation based on the Article 1

\footnotetext{
http://m.rmol.co/news.php?id\&gt;

www.hukumonline.com (2706 2006)

${ }_{3}^{3}$ Jimly Asshiddiqie, Hukum Acara Pengujian Undang-Undang, (Jakarta: Konstitusi Press, 2006), p. 37-39.

${ }^{4}$ Peter Mahmud Marzuki, Penelitian Hukum, Kencana, Jakarta, 2009, p.35

${ }^{5}$ Ibid.

${ }^{6}$ R. Joeniarto,1992, Perkembangan Pemerintahan Lokal, Penerbit Bumi Aksara, Jakarta, hal .8

Afan Gaffar dalam Juanda H. Op.Cit, hal.83.

${ }^{8}$ Juanda H. Ibid, hal..85.
} 
Paragraph (2) of the 1945 Constitution as stated "Sovereignty is in the hands of the people and fully carried out by the People's Consultative Assembly". The principle of sovereignty is sovereignty in the hands of the people, while representative deliberation is the responsibility of the People's Consultative Assembly as the incarnation of all people who hold the total sovereignty of the people.

According to Strong, the essence of democracy is not separated from the people and the sovereignty of the people as stated: "By democracy in this sense we therefore mean a system of government in which the majority of the grown members of a political community participate through a method of representation which secures that the government is ultimate responsible for its actions to that majority. In another words, the contemporary constitutional state must be based on system of democratic representation which guarantees the sovereignty of the people"l.

According to Soemitri (in Muluk) ${ }^{2}$, the law on Regional Government regulates properly on autonomy and medebewind. The matters that are submitted to the regions are not becoming the field of the public's interest, because they have been regulated in separate regulations and the remaining functions that are not specified become the functions of the autonomous regions. However, regional government as an autonomous region has the authority in administering democratic regional government in accordance with the elaboration of the 1945 Constitution, that regional government is held based on the principle of deliberation or democracy. Hence, regional government has the right to regulate and manage government affairs based on the aspirations and interests of the community.

\section{A. The Essence of Local Government Regulation in Regional Autonomy}

Local government Regulations are legal norms whose material is regulatory and generally applicable and consists of an abstract content. In this context, the Head of the Region may stipulate the Decree of the Regional Head in accordance with the delegation obtained from the Articles (decree) of the Local government Regulation and by the power of other applicable laws and regulations. Manan explains the general abstract with a meaning tha it is not directed at specific concrete objects, events or symptoms ${ }^{3}$. As a legal norm, Local government regulations are instruments or means for the government to run the activities of government and to resolve social problems. In addition, it functions as a director, engineer and designer as well as a driver for change and community behavior. Local government Regulations are the main keys in the implementation of regional government based on the law in the 1945 Constitution, the results of the amendment that have been determined as a state format explicitly mentioned in the Article 1 Paragraph (3) of the 1945 Constitution. Thus, all aspects of social life, particularly in the context of the administration of regional government (the relationship between regional government and its people) and in the relationship between residents of the community in the area, are now regulated and compulsory based on Local government Regulations. Therefore, Local government Regulation s no longer requires the approval of the authority of state institutions in the Central Government. In this connection, the scope of the material within the Local government Regulation is limited only on the authority of the Regional Government to regulate and manage the management and household of its government.

\section{B. The Implications of Local Government Regulation in the National Legislation System}

Based on a system of gradual legal norms (stufentheory) adopted by Indonesia, a product of legislation must not be in conflict with higher statutory regulations. Based on the authority of the regional government related to regional autonomy, all regional authorities (mandatory and optional affairs), can be a subject to the Decree content of local government Regulation as long as they do not conflict with the higher authority of laws and regulations and public interest.

If there is a conflict of Local government Regulation in a regency that contradicts with a Local government Regulation in another regency, it essentially has no legal implication, because each regency has authority in its autonomous region. Otherwise, when the local government Regulations are issued having any implication that intersect with the interests of other regions, it must be resulted in disputes. In this context, the role of the central government is to resolve through administrative mechanisms. Legal remedies for resolving conflicts between autonomous regions and the government that are rooted in the cancellation of autonomous regional legal products should not be based on the analogy of resolving conflicts between the state constitution and the federal constitution through the Supreme Court. Like in the Unitary State, the autonomous regions are the creation of the government. Thus, the autonomous region is only possible to take legal efforts through administrative efforts.

The substance of the Local government Regulation is the further description of the higher constitutional law. However, further elaboration of higher regulations or policies by lower government units can be carried out within the framework of co-administration and de-concentration of tasks. The regencies and cities do not have a deconcentrated relationship with higher government units. Therefore, Local government Regulations are only possible in the task of assistance. The province has a de concentrated relationship with a higher government unit (central government). However, this relationship is not in line with the Provincial Government, but with the

\footnotetext{
${ }^{1}$ C.F. Strong, 1966, Modern Political Constitusinal, Sidgwick \& Jackson Limited London E.L.B.S Edition First Published, p.13

${ }^{2}$ Soemitro dalam M.R.Khairul Muluk, Op.Cit.p. 134

${ }^{3}$ Bagir Manan, ---------1993, Perjalanan Historis Pasal 18 UUD 1945 (Perumusan dan Undang-Undang Pelaksananya), (Kerawang: Unsika), p. 123.
} 
governor as the representative of the Central Government. By that, it is impossible to form Local government Regulation to implement a task of deconcentralization.

\section{Judicial Review on Local Government Regulation}

Local government Regulations has a strategic position in the state's and nation's life. The strategic position of the Local government Regulation can be well achieved if the formation of the regulation is done well. As viewed in the legislation, the local regulation has a unique position, because although the local regulation is under the law, there is no any unity of opinion among experts with an authorized quality to test it.

Furthermore, Soemantri explains that there are various ways of canceling regulations, because there are several parties who have the right to test the regulations. The right of the trial is conducted not only by the Supreme Court, but also by the government, the President, and the Ministry of Home Affairs ${ }^{1}$. Meanwhile, Asshiddiqie states, "Local government Regulations as a result of the work of the Regional Head and Regional Representative Council (DPRD) cannot be cancelled by a unilateral decision from the central government" ${ }^{\text {. }}$

Practically in any literature, there two types of the trial (toetsingsrecht or Review), namely: (1) formal trial (formele toetsingsrecht); and (2) the right to test material (materiele toetsingsrecht) ${ }^{3}$. The right to test formally is the authority to judge whether a product of a statutory regulation is manifested through methods (procedures) as specified or regulated in applicable laws or regulations. For example, a law is a legal product established by the House of Representatives (see the Article 20 Amendments to the 1945 Constitution). The President has the right to submit a legal draft to the House of Representatives and each draft is discussed by the House of Representatives and the President for mutual agreement (see the Article 5 jo 20 paragraph (2) Amendments to the 1945 Constitution). Therefore, the legal product must also be formed based on the procedures mentioned above ${ }^{4}$.

A legal product cannot be called a local regulation if it is only determined by the Governor/Regent/Mayor without any approval from the House of Representatives (DPRD). Strictly speaking, the formal test rights are related to the form of laws and regulations that are formed as well as the procedures for their formation. On the other hand, the right to test material is an authority to investigate and assess (1) whether a statutory regulation is in accordance with or contradictory to a higher degree, and (2) whether a certain authority (verordenende macht) has the right to issue a certain regulation or not. Therefore, the right to test the material regarding the content of a law has a relation to higher-level regulations ${ }^{5}$.

In addition, the mechanism for the revocation of Local government regulation can also be called as a judicial review mechanism, but it is not carried out by the judiciary or by the legislator, but by a top-level (central) executive government agency ${ }^{6}$. However, the measuring or appraisal barometer used by the testing agency (the central government) is not the Constitution, but the law. The reason for the cancellation of these local government Regulation s is solely, that they are considered to violate the provisions of the law as the higher in the hierarchy of law and regulation in force in Indonesia context. Therefore, the definite test cannot be mentioned as constitutional review ${ }^{7}$.

\section{The Cause of Cancellation of the Local government Regulation}

Indonesia has come up the era of regional autonomy; widely since the enactment of Law Number 22 of 1999 until the enactment of Law Number 23 of 2014. In this era, the Parliament and Regional Government are given the freedom to regulate their regions by making Local government Regulation (PERDA). Freedom tends to be used as widely as possible. The restrictions in the form of cancellation of Local government Regulation have become necessary. Without restrictions, regions have the potential to make local regulations that are not in line with the Unitary States of the Republic of Indonesia (NKRI) principles and the basis-direction of national policies. The data show that number of local regulations will be canceled by the Ministry of Home Affairs. Based on the Law No. 23 of 2014 concerning Regional Government in the Article 250 paragraphs (1) and (2), states that local regulations are prohibited from conflicting with the provisions of higher laws, public interests, and/or decency. In detail, the explanation is referred to as follows.

\section{Contrary to the Provisions of the Higher Law and Regulation Agency (PUU)}

In drafting a Local government Regulation, the legislators and drafters cannot freely formulate a regulation. They must consider the higher law and regulation agency (PUU), such as the 1945 constitution, Laws,

\footnotetext{
${ }^{1}$ News was taken from the website www.hukumonline.com (27 06 2006). In line with Prof. Sri Soemantri, Director of the Center for Law and Policy Studies (PSHK), Bivitri assesses that local government Regulation s can be carried out by excecutive review and judicial review; "Sebenarnya ada dua lembaga (yang berwenang me-review). Pertama, (berdasarkan) Pasal 145 Undang-Undang Nomor 32 Tahun 2004 ada kewajiban mengirimkan semua perda yang sudah ditandatangani ke Departemen Dalam Negeri. Dalam dua bulan, Departemen Dalam Negeri seharusnya me- review. Kalau misalnya (perda) tidak sesuai peraturan perundang-undangan terkait, bisa dibatalkan. Kalau kemudian Pemda dan DPRD tidak puas, bisa challenge ke MA. Kemudian yang kedua (oleh) MA, melalui mekanisme judicial review".

${ }^{2}$ Jimly Asshiddiqie, Hukum Acara Pengujian Undang-Undang, (Jakarta: Konstitusi Press, 2006), p. 37-39.

${ }^{3}$ Henry P. Panggabean, Fungsi Mahkamah Agung Dalam Praktik Sehari-hari (Upaya Penanggulangan Tunggakan Perkara dan Pemberdayaan Fungsi Pengawasan Mahkamah Agung), (Jakarta: PT. Pustaka Sinar Harapan, 2001), p. 127

${ }^{4}$ Article 236 paragraph (2) d of Law Number 23 Year 2014

5 Ibid.

${ }^{6}$ Ni'matul Huda, Regional Government Law, (Bandung: Nusa Media, 2009), p. 134.

${ }^{7}$ Jimly Asshidiqie, Models of Constitutional Testing in Various Countries, (Jakarta: Constitution Press, 2005), p. 74-75.
} 
Governmental Regulations, and Presidential Regulations. This is in accordance with the legal principle of lex superiori derogat legi inferiori, that if there are differences in regulations, the provisions of the higher level of law and regulation should paralyze the lower level of statutory provisions. Thus, the Local government regulation becomes invalid when it contradicts with the higher regulation agency.

\section{Contrary to Public Interest}

The Local government Regulations that are enacted may not result in disruption of harmony among citizens, disruption of access to public services, disruption of public order, disruption of economic activities to improve community's welfare, and discrimination against ethnicity, religion and creed, race, intergroup, and gender. According to the Article 250 paragraph (2) of Law No.23 of 2014, the public interest includes:

(a) Disturbance of harmony among community's members;

(b) Disruption of access to public services;

(c) Disturbance of peace and public order;

(d) Disruption of economic activities to improve the welfare of the community; and/or;

(e) Discrimination against ethnicity, religion and beliefs, race, ethnicity, and gender.

Since Local government regulations are local (local wet) legislation, the term 'public interest' only covers the local area. The problem is, what measurement tools are used by the Central Government in interpreting whether or not a regulation is in conflict with the public interest, given the large number of regions both provinces and districts/cities spread throughout Indonesia with pluralistic and pluralistic patterns of society?

\section{Contrary to Decency}

The local government regulation to be enacted must not be in conflict with the norms relating to manners and manners, behavior, and manners of the community where the law applies. The formulation of decency until now is still multiple interpretations and has no legal certainty. Referring to the opinion of Aries Harianto $^{1}$, decency is a value of behavior especially that arouse lust based on local ethical awareness as a manifestation of the collective feelings of the local community.

\section{E. Contradicting the Legitimacy of the Right to Test Local government Regulations}

In Indonesia, the amendment to the 1945 Constitution of the Republic of Indonesia has brought changes in the life of the state administration, especially in the practice of judicial authority. Based on these changes, the judicial power is practiced by a Supreme Court and the judiciary bodies in the general court, religious court, military court, state administrative court, and by a Constitutional Court ${ }^{2}$. Accordingly, the right of judicial review for the Constitution is given to the Constitutional Court, while the right to test the statutory provisions under the law against the law is given to the Supreme Court.

In the 1945 Constitution, the power of the judiciary is described as an independent power to administer justice to enforce law and justice based on Pancasila. The free judicial power implies that judicial power is free from any interference by extra judicial powers, except in matters referred in the 1945 Constitution of the Republic of Indonesia. Freedom of practicing the judicial authority is not absolute, because the duties of the judge are enforcing the law and justice in accordance with Pancasila, so that the verdict reflects the sense of justice of the Indonesian ${ }^{3}$.

According to Asshiddiqie, the system adopted and developed according to the 1945 Constitution is centralized model of judicial review. As determined in the Article 24A paragraph (1) and the Article 24C paragraph (1) of the 1945 Constitution, the system adopted is a centralized system. Therefore, the choice of test is held by the Supreme Court or the Constitutional Court. As if the authority of local government Regulation s is given to the Supreme Court, it means that the Local government Regulation is absolutely seen as only one form of legislation under the law. Therefore, despite the fact that the Local government Regulation is also a product of "legislative acts", but the provisions of the Article 24A paragraph (1) of the 1945 Constitution has indicated that the test can absolutely only be carried out by the Supreme Court ${ }^{4}$.

In the Article 9 paragraph (2), the phrase 'statutory regulation under the law' has manifested that Local government regulation as a type of statutory regulation under the law, and its judicial review authority is absolutely carried out by the Supreme Court. This is confirmed by the Article 24A paragraph (1) of the 1945 Constitution that "the Supreme Court has the authority to adjudicate at the cassation level, test the statutory provisions under the law against the law, and have other powers granted by the law".

Somewhat different as mandated in the 1945 Constitution that gives the authority to test the laws and regulations (esp. Local government Regulation ) to the Supreme Court as the executor of a free and independent judiciary without any interference from extra judicial institutions. In the perspective of Law No. 12 of 2011

\footnotetext{
${ }^{1}$ Aries Harianto, A Dissertation: Makna Tidak Bertentangan dengan Kesusilaan sebagai Syarat Sah perjanjian Kerja, p. 308. This dissertation is approved and presented to the board of examiners in December 30, 2013 on the Doctoral Program of Law, Faculty of Law, University of Brawijaya, Malang.

${ }^{2}$ J imly Asshidiqie, Pokok-Pokok Hukum Tata Negara Indonesia Pasca Reformasi, PT. Buana Ilmu Populer, Jakarta, Cetakan Kedua, 2008, p. 515.

${ }^{3}$ Ibid., p. 51

${ }^{4}$ Ibid., p. 257
} 
concerning the Formation of Legislation, in a hierarchy, the Supreme Court has the right to test the Governmental Regulations, Presidential Regulations, and Regional (Provincial and District/City) Regulations both materially and formally. The legal basis for the right to test is also regulated in the 1945 Constitution of the Article 24A paragraph (1). In addition, there are other legitimacy of authority, such as the Article 9 paragraph (2) of Law No. 12 of 2011 concerning the Formation of Laws and Regulations, the Article 11 paragraph (2) letter b of Law No. 4 of 2004 concerning Judicial Power, and the Article 31 paragraph (2) of Law No. 5 of 2004 concerning the Supreme Court.

There is a conflict of legitimate authority that is regulated by the Constitutional Law and the Law itself. The mechanism of 'executive review' carried out by the central government is legitimized by the Law No. 32 of 2004 concerning Local Government, while the authority of the 'judicial review' conducted by the Supreme Court has the legitimacy of the 1945 Constitution (the Article 24A paragraph (2) and the law No. 11 of 2011, the law No. 4 of 2004, and the law No. 5 of 2004. However, practically, the Supreme Court is only passive in the sense of expecting an appeal from the petitioner who feels the cancellation of the central government is detrimental applicant party, but only the central government is active in judicial review on local government regulation.

From each of the legitimate authority, there is a relation with the differentiation of the standardization of local government regulation both through the mechanism of 'executive review' conducted by the central government and 'judicial review' by the Supreme Court. The central government (in its testing) can be categorized as broad standardization, because testing is not only carried out with the highest standards of legislation, but also based on the opposition to the public interest. Meanwhile, the Supreme Court tests local government Regulation s based on an assumption whether or not the regulations are contradictory to the highest laws (material trial) and the making of local regulations is in accordance with the steps or procedures set out in the law and regulation (formal trial).

If local government regulations in the interpretation of legal politics (law as a political product) are the formulations of political conflicts, political domination, political forces among legislative and executive institutions through elections with a very prominent role of political parties, it is most likely in the process of judicial review on local regulations carried out by the central government will sense political. Therefore, local government regulations as a political product cannot be tested by political institutions that are fundamentally laden with political interests. The phrase 'violating the public interest' can only be interpreted as based on political power. For example, the local government regulations that have been passed can sometimes cause resistance reactions from the community.

Otherwise, if the government cancels the local government regulation, there is an initiative by the regional government or the community to object it to the Supreme Court. This evidence indicates that the interpretation of the public interest always has a political dimension, because the test is a political institution not a judicial institution whose existence cannot be intervened by the extreme judiciary institutions. Therefore, local government Regulation s can be said qualified or not depending on the political interpretation of the central government.

The construction of the above ideas can also be traced to the arguments presented by Huda that if local government Regulations as political products are tested and cancelled by political institutions through mechanisms that are also political with presidential regulations, the political parties will be confronted. The political process that has been completed at the regional level is continued by the political process at the central level ${ }^{1}$.

\subsection{The Executive Review after the Constitutional Court Decision Based on Political Perspective of the National Law}

The Constitutional Court's Decision No. 137/PUU-XIII/2015 on Law judicial review case No. 23 of 2014 concerning Regional Government submitted by the Indonesia Association of Regency Government (APKASI) with the verdicts: Granting the petition (APKASI) during the testing of the Article 251 paragraph (2), paragraph (3), and paragraph (8) and paragraph (4) along the phrase "... the cancellation of Regency/City Local government Regulation s and Regents/Mayor Regulations as referred to in paragraph (2) is determined by the delegation of the governor as the representative of the Central Government". The law No. 23 of 2014 concerning Regional Government (State Gazette of the Republic of Indonesia No. 244 of 2014 and Supplement to the State Gazette No. 5587); Stating the phrase "Regency/City Regulation" in the Article 251 paragraph (2) and paragraph (4), in the Article 251 paragraph (3), and the phrase "the organizer of the Regency/City Regional Government cannot accept the decision to cancel the Regency/City Regulation", and phrase "the Regency/City Regulation" in Article 251 paragraph (8) of Law No. 23 of 2014 concerning Regional Government (LN RI 2014 No. 244 and TLN No. 5587), are said contrary to the 1945 Constitution of the Republic of Indonesia and do not have a binding legal force.

There is a decision of the Court as far as the Local government regulations. In this context, the four constitutional justices namely Arief Hidayat, I Dewa Gede Palguna, Maria Farida Indrati, and Manahan MP Sitompul have different opinions (dissenting opinions) as follows.

1. ... that there is a specificality for the argument of the Petitioners in the examination of Article 251 paragraph

(1), paragraph (3), paragraph (4) and paragraph (8) and paragraph 3 of the 1945 Constitution. The

\footnotetext{
${ }^{1}$ Ibid., p. 254
} 
fundamental case in the constitutional norm is the principle that the Unitary States of the Republic of Indonesia (NKRI) will apply a legal system for the government at the central and regional levels. Therefore, in a unitary state, no matter how extensive the autonomy granted to the regions (as affirmed in the Article 18 paragraph (2) of the 1945 Constitution and the Article 18 B paragraph (1) of the 1945 Constitution. Therefore, it is precisely a statement in the general explanation of the Regional Government Law that states the grant of autonomy to the fullest extent shall be carried out based on the principle of a unitary state. In a unitary state, sovereignty is only in the state government or national government and there is no sovereignty in the region. No matter how great an autonomy is given to the region, the final responsibility for the implementation of the Regional Government will remain in the hands of the central government. For this reason, the Regional Government in a unitary state is a unity with the National Government. The region as a legal community unit that has autonomy, has an authority to regulate and manage their regions in accordance with the aspirations and interests of their communities as long as they do not conflict with the national legal order and the interests of the general public.

2. ... that the norm of the Article (251 of the Regional Government Law reads as follows:

(a) Provincial regulations and governor regulations that contradict with higher laws, public interests, and/or decency are canceled by the Minister.

Regency/City regulations and regent/mayor regulations that conflict with higher statutory regulations, public interests, and/or decency are cancelled by ministers as representatives of the Central Government.

(c) In the case of governor as a representative of the Central Government, he does not cancel Regency/City Regulations, and/or regents/mayors regulations that contradict with higher laws, public interests, and/or decency as referred to paragraph (2) of the Minister to cancel Regency/City regulation and/or regent/mayor regulation.

The cancellation of provincial regulations and governor regulations as referred to paragraph (1) shall be determined by the Ministerial Decree and the cancellation of Regency/City Regulations and/or regent/mayor regulations as referred to paragraph (2) shall be determined by Governor's decision as a representative of the Central Government.

At the latest seven days after the cancellation decision as referred to paragraph (4), the Head of Region must stop the implementation of the Local government Regulation and subsequently the House of Representatives (DPRD) as well as the Head of Region has revoked the stipulated regulation.

At the latest (7) days after the decision on cancellation as referred to in paragraph (4), the regional head must stop the implementation of the Local government Regulation and subsequently the regional head revokes the said Local government Regulation .

In a case that the organizer of the Provincial Government cannot accept the decision to cancel the Provincial Regulation and the Governor's Regulation cannot accept the decision to cancel the Governor Regulation as referred to paragraph (4) for reasons that can be justified by the provisions of the Governor Act. Then, the objection may be submitted to the President at the latest fourteen days from the period that the decision to cancel the Local government Regulation or Governor Regulation is accepted.

(h) In a case that the organizer of the regency/city government cannot accept the decision to cancel the regent/mayor's regulations as referred to paragraph (4) for reasons that can be justified by the provisions of the legislation, the regent/mayor can submit an objection to the Minister at least fourteen days after the decision to cancel the regency/city regulation or regent / mayor regulation is accepted.

3. The Article 251 of the Regional Government Law must always be based on an understanding that the authority of the Regional Head and Regional Representative Council to form a Regional Government Regulation is the authority of attribution which can only be granted and implemented by the Constitution and the Law (like the Article (18 paragraph 16) of the 1945 Constitution and Article 236 of Law No. 23 of 2014). The Local government Regulation is not a delegation of regulation from the Act (the Regional Government Law), because if it is so, this matter has contradicted the principle of delegatie van wetgevingsbevoegheid, that is the devolution of authority in forming legal regulations of all higher regulations against the lower regulations.

4. The nature of 'cancellation'. In this case, cancellation can be made by the official who makes the decision, the head of the official who makes the decision or the court (e.g. the Civil Service Arbitration Tribunal (PTUN)). In the context of a quo petition, a legal rationality is acceptable if cancellation is applied to Local government Regulation, because, the President is constitutionally responsible for the highest government. Thus, it is implicitly the President's obligation to take an action on legal products, administrators of defective government in the sense of being contrary to the higher statutory regulations, public interest, 
and/or decency.

5. According to the Article 4 of the 1945 Constitution, the President is the holder of the power of government. Therefore, it is precisely the formula as referred in the Article 1 No. 1 of the Regional Government Law which says that the Central Government is the President of the Republic of Indonesia, assisted by the Vice President and the Minister as referred to the 1945 Constitution. In other words, the responsible person for the overall implementation of government is the President as confirmed in the Article 1 paragraph (1) of the 1945 Constitution of the Republic of Indonesia. The Regional government is part of the exercise of governmental power. According to the Article 18 of the 1945 Constitution of the Republic of Indonesia, the regions are given the widest possible autonomy to hold the government and remain the President. Therefore, it is constitutional if the President through the Minister of State and governor as the representative of the Central Government in the region, is given the authority to cancel the Local government Regulation .

6. According to the Article 1 No. 2 and No. 3 of the Regional Government Law, they are both elements of the regional administration. The Local government Regulation based on the Article 236 paragraph (2) of the Regional Government Law is a joint product of the Regional House of Representatives (DPRD) and Head of Region whose material can contain the implementation of regional autonomy. Thus, Local government Regulation $\mathrm{s}$ are a joint product of elements of regional government whose material content is government affairs while the Article 1 No. 5 of the Local government Regulation stipulates that governmental authority (under the authority of the President) is carried out by state ministers and regional government administrators to protect, serve, empower, and prosper the community.

7. The act of cancellation must be distinguished from judicial review or statutory regulations testing. The authority of a judicial review is a part of the authority of a judicial authority which can be appealed by parties who feel disadvantaged by the enactment of a statutory regulation, in-casu of local government Regulation. Meanwhile, the cancellation is a part of the governance power (executive). Therefore, the Regional Government Law that gives an authority to the President (through the minister and governor) to cancel the Local government Regulation and Local government Regulation, is not intended to replace the expert of judicial review authority in the hands of judicial power holders. It means that the law of the Local government Regulation does not hinder and eliminate the rights of the damaged parties by the establishing of local government Regulation to propose judicial review.

The NKRI principles are mentioned five times in the 1945 Constitution, namely the Article 1 paragraph (1), the Article 18, the Article 18B paragraph (3), the Article 25A and the Article 37 paragraph (5). The Article 1 paragraph (1) of the 1945 Constitution confirms, "The Republic of Indonesia is a Unitary State in the form of a Republic", and the Article 18 paragraph (1) of the 1945 Constitution mandates "The Unitary State of the Republic of Indonesia is divided into provinces and provincial areas divided into regencies and cities, which each province, district and city has regional government regulated by Law". Based on the provisions of the Article 18 paragraph (2) of the 1945 Constitution that "The provincial, regency and city government regulate and manage their governmental affairs according to the principle of its autonomy and co-administration" to facilitate servants, shorten the distance between the government as an employee and the public as a party being served, efficient, and effective in the implementation of central government to advance community's welfare in an area.

According to Sumantri, the delegation of authority from the Central Government to autonomous regions is not stipulated in its constitution, because it is the essence of the unitary state ${ }^{1}$. The Article 18 paragraph (5) of the 1945 Constitution mandates "Regional governments exercise an autonomy to the possible greatest extent, except for governmental affairs that are determined by the Law as central government affairs". Based on the provisions of the Article 18 paragraph (2) of the 1945 Constitution, the existence of regional government has constitutional authority to regulate and manage their own government affairs according to the principle of autonomy. Likewise, the will of the constitution in the Article 18 paragraph (5) of the 1945 Constitution to bring autonomy to the widest possible extent with its way to provide the widest possible area for regions to regulate and manage their own government affairs, is the realization of decentralization of the democratic governance.

The authority of the Central Government is practiced by the President, and the Regional Government is practiced by the Regional Government and the Regional House of Representatives (DPRD). With this division of authority, the position of the Local government regulation becomes highly important in carrying out the functions of regional government. The supervision conducted by the President on Local government Regulation is repressive. The lack of oversight by the Central Government over the Local government Regulation will weaken the Central Government in controlling the Regional Government, especially when the Central Government is obliged to protect the public interest from the arbitrariness of the early Regional Government.

The effort to find the ideal format of relations between the Central and Regional Government within the framework of a unitary state is not an easy matter, because it is a process that goes hand-in-hand with the nation's

${ }^{1}$ Sri Sumantri M, Introduction to Comparative Inter-Law Tatanegara, Rajawali, Jakarta, 1981, p. 52 
life. The issue of the relationship between the Central and Regional Government in the Unitary State with the autonomous unit in addition to being connected to the method of determining regional household affairs also originates from the relationship of authority, supervisory relationship, financial relationship and other relationships arising from the organizational structure of government in the region. In a large organization and adopted notion of democracy, also held the expectation of decentralization. This principle serves to create diversity in the administration of government in accordance with the condition and potential of the community.

Based on the Article 9 paragraph (1) and paragraph (2) of Law No. 23 of 2014 concerning Regional Government, states that government affairs consist of absolute government affairs, concurrent affairs and general government affairs. The Article 9 paragraph (2) states that absolute government affairs as meant in paragraph (1) are government matters with full authority of the Central Government. It is not possible to abandon the principle of centralization in the centralization of state organization, because the two principles are not dichotomous but continuum. Therefore, regional autonomy requires government guidance and supervision, so that it does not transform into sovereignty. In addition, the Article 10 paragraph (1) of Law No. 23 of 2014 also states that the absolute government affairs as referred to the Article 9 paragraph (2) include: (a) Foreign Policy, (b) Defense, (c) Security, (d) Justices, (e) National Monetary and Fiscal, and (f) Religion. The regional autonomy and autonomous regions are the creations of the government. However, the relationship between autonomous regions and the government is the relationship of responsive organization ${ }^{1}$.

In the system of unitary state, there are two method that can connect between the Central and Regional Government. The first method is centralization; where all the affairs, duties, functions, and authorities of the organization of actor are in one group whose implementation is carried out deconcentratedly. The second method is decentralization; where the functions, duties and authority of the implementation of the actor are left to the possibly greatest extent for the regions ${ }^{2}$. Although centralization and decentralization can be distinguished, they cannot be clearly separated, because they are mutually exclusive. In the same context, Surianingrat argues that centralization and decentralization are inseparable, interrelated and influence each other. ${ }^{3}$ Centralized and decentralized are the two ends of a piece of line.

For Mahfud MD, regional autonomy is the grant of freedom to manage one's own household without ignoring the position of the regional government as the Central Government apparatus to carry out the functions assigned to $\mathrm{it}^{4}$. The essence of regional autonomy is the grant of authority to the region to manage and regulate regional households to realize community's welfare. Autonomy is also interpreted as something that means freedom or independence (zelfstandigheid), but not independence (onaafhankelijkheid). The limited freedom or independence is a form of providing opportunities that must be accounted for ${ }^{5}$.

The purpose of granting autonomy to the region includes the following aspects: ${ }^{6}$

a. In the political point of view, it is to include and channel the aspirations of the community, as well as to support national politics and policies in the frame of development and democratic processes in the lower lining.

b. In terms of management, it is to improve the effectiveness of government administration, especially in providing services to the community.

c. In terms of society, it is to separately increase participation and foster community independence by undertaking community's empowerment efforts (enpowering).

d. In the economic point of view, it is to expedite the implementation of development programs to achieve an improved public welfare.

In terms of the relationship between the Central and Regional Government, supervision is a binding unit, so that the stimulus of freedom of theautonomy does not move so far. Terry defines the term supervision is determining what has been achieved, evaluating and implementing corrective actions as well as ensuring results that are in accordance with planning ${ }^{7}$. Bagir Manan, views control as a function and rights at the same time. It is commonly called as control function or rights control. ${ }^{8}$ Basically, a control contains the dimensions of supervision and control itself. Thus, the supervision deals with restrictions and controls related to some directions.

As connected with supervision of the government, it appears that the general understanding of supervision is

${ }^{1}$ Bhenyamin Hoessein, "Relationship between Central and Regional Authorities", in Soetandyo Wignosubroto et al., Tides of Regional Autonomy in Sketches of the Hundred Years Journey, Institute for Local Development Tifa Foundation, 2005 , p. 199.

${ }^{2}$ Sarundajang, 2000, Central Power Return to the Regions, Jakarta, Pustaka Sinar Harapan, p. 32.

${ }^{3}$ Fri. Anggriani, Position Qanun In the Regional Government System and Supervision Mechanism, Journal of Law Ius Quia Iustum Faculty of Law, Islamic University of Indonesia, Yogyakarta, Volume 18 No 3. July 2011, p. 324.

${ }^{4}$ Mahfud MD, Political Law in Indonesia, Op.Cit, p. 93. Applied in Lintje Anna Marpaung, 2012, Rationalization of Local Wisdom-Based Regional Expansion Processes (Study of Regional Expansion in Lampung Province), Semarang Dissertation of PPDIH of Diponegoro University, p. 54

${ }^{5}$ Ateng Syahfrudin, 1985, Regional Autonomy Tides, Bandung, Binacipta, p. 5

${ }^{6}$ Sarundayang, Reverse Flow ..., Op.Cit, p. 36

${ }^{7}$ George R. Terry, Principles of Management, Translated by Winardi Alumni Bandung, 1986.

${ }^{8}$ Bagir Manan, "Enhancing the Function of Community Control Against the Executive and Judicial Legislative Institutions", Paper at the Kosgoro National Level Orientation and Face-to-Face Forum, Cipanas - Cianjur, July 26, 2000 p. 1-2. 
still relevant due to some reasons, namely: first, the general objective of supervision of the government is the maintenance or safeguarding, so that the welfare state can run well and bring government power as the implementation of public's welfare; second, the benchmarks are laws that regulate and limit the power and actions of government in the form of material laws and formal laws (Rechtmatigheid) and their benefits for the welfare of the people (doelmatigheid); third; there is a match between actions and benchmarks that have been set; fourth, if there are number of signs, there will be a deviation from the benchmarks to take preventive measures; and fifth, if the verification shows that there has been a deviation from the benchmarks, then corrections are made through the action of cancellation, recovery of the consequences and discipline of the actor of the error ${ }^{1}$.

Based on the law No. 32 of 2004, the legislation that has been passed at the regional level can be cancelled or declared null and void by law. Cancelled means that the invalid validity comes from the date of cancellation, while null and void means that the invalidation is effective from the time the regulation was established. In that connection, a supervision consists of two channels, namely supervision through the executive channel (Central Government) and supervision through the judicial channel (the Supreme Court) ${ }^{2}$.

\section{Conclusion}

Based on the result of the research, it can be concluded as follows:

1. In the perspective on local government autonomy, although there is already a clear frame on the content of the Local government regulation, each region can draw up a Local government regulation whose material content also accommodates the specific condition of a particular region. This shows that the formation of local government regulation must also open the space of local content into the content of a Local government regulation. The contents of the local content could have been lifted from the customs of the local community and the values that stand out in the area. In other word, the existence of local government regulation that has these characteristics is a necessity that requires a philosophical and sociological justification of the local area.

2. The executive review after the decision of the Constitutional Court is in accordance with the national legal politics, because the cancellation of a Local government Regulation by the Minister of Home Affairs is basically based on the Indonesian laws and the regulation is not in accordance with the mandate of the 1945 Constitution of the Republic of Indonesia as it has been legally valid and can only be done by the Supreme Court in accordance with the Article 24A paragraph (1) of the 1945 Constitution.

\section{Suggestion}

Based on the analysis, the authors provide the following recommendations:

(1) In the consideration of accommodating local values as a consequence of the implementation of regional autonomy, it is the time for the government to review the regulation which has become the government's authority. In the sense of an urgency to do a revision (legal reform) on the existing laws and regulations, especially the law No. 23 of 2014 concerning Regional Governments, the embodiment of the existing Local government Regulation test/trial does not necessarily use absolute parameters which (in fact) actually negates the local value.

(2) The embodiment in the form of revision (legal reform) and the formation of new law and regulation to overcome the existing authority bias, it is the time for the government to make arrangements by adding the functions and authority of the Supreme Court.

\section{References}

AM. Mujahidin. "Pemulihan Hukum Yang Berkeadilan Di Era Reformasi Menuju Kesejahteraan Masyarakat" Jurnal Varia Peradilan No.301 Desember 2010

Anthon F. Susanto, Wajah Peradilan Kita, Konstruksi Sosial tentang Penyimpangan, Mekanisme Kontrol dan Akuntabilitas Peradilan Pidana, Refika Aditama, Bandung, 2004.

Arfan Faiz M. "Reposisi Lembaga Pendidikan Hukum dalam Proses Legislasi di Indonesia", Jurnal Konstitusi MKRI, Vol.6, Nomor 2, Juli 2009

Astim Riyanto. Teori Konstitusi. Bandung : Yapemdo. 2000.

B. Arief Sidharta, 2000, Wajah hukum di era Reformasi: kumpulan Karya Ilmiah Menyambut 70 Tahun Prof. Dr. Satjipto Rahardjo, Bandung: Citra Aditya Bakti.

Bajongga Aprianto, 2006, Problematika Hukum Hak Uji Materiil dan Formil Peraturan Daerah, Jakarta: Ghalia Indonesia

C.F. Strong, Modern Political Constitution: An Introduction to the Comparative Study of Their History and Existing Form, diterjemahkan menjadi Konstitusi-Konstitusi Politik Modern, Kajian Tentang Sejarah dan

\footnotetext{
${ }^{1}$ Irfan Fachruddin, Supervision of Administrative Justice Against Government Actions, Bandung Alumni, 2004 , p. 90 - 91

${ }^{2}$ Jimly Asshiddigie, HK Judicial Review Program, second note, Secretariat General and RegistrarMK RI, Jakarta, 2006, p. 1.
} 
Bentuk-Bentuk Konstitusi Dunia oleh SPA Teamwork, Bandung: Nuansa dan Nusamedia, 2004).

Fatkhurohman, 2009, "Pengaruh Otonomi Daerah Terhadap Hubungan Pemda di bidang Regulasi untuk menangani Perda Bermasalah (Studi di Kabupaten Malang)”, Jurnal Hukum Yustisia, FH UNS Surakarta, Tahun XXI. Januari-April 2010

H.M. Arsyad Sanusi, "Keadilan Substantif dan Problematika Penegakannya”, Jurnal Varia Peradilan No. 288 November 2009

HAW Widjaja,2001, Otonomi di Titik Beratkan pada Daerah Tingkat II, Penerbit PT Grafindo Persada, Jakarta.

Henry P. Panggabean, Fungsi Mahkamah Agung Dalam Praktik Sehari-hari (Upaya Penanggulangan Tunggakan Perkara dan Pemberdayaan Fungsi Pengawasan Mahkamah Agung), (Jakarta: PT. Pustaka Sinar Harapan, 2001).

Hestu B.Cipto Handoyo,2009, Hukum Tata Negara Indonesia, Penerbit Universitas Atma Jaya, Yogyakarta.

Hilaer Barnett, Constitutional And Administrative Law, (London: Queen Mary, University,of London Cavendish Publishing Limited : 2002).

Imam Koeswahyono, "Partisipasi Masyarakat Dalam Proses Pembuatan Kebijakan Negara Suatu Telaah Plurarisme Hukum” Jurnal Arena Hukum, Fak. Hukum Universitas Brawijaya, Nomor 3 Tahun 2 Januari 2009

Irfan Fachruddin. Pengawasan Peradilan Administrasi terhadap Tindakan Pemerintah. Bandung: Alumni, 2004.

Jazim hamidi, "Paradigma Baru Pembentukan dan Analisis Peraturan Daerah (Studi Atas Perda Pelayanan Publik dan Perda Keterbukaan Informasi Publik)," Jurnal Hukum No. 3 Vol. 18 Juli 2011

Jimly Asshiddiqie, "Peraturan Daerah Sebagai Bagian Integral Dari Peraturan Perundang-undangan dalam Negara Hukum RI”, Jurnal Legislasi Daerah Edisi I Januari-April 2010

Jimly Asshiddiqie, Hukum Acara Pengujian Undang-Undang, (Jakarta: Konstitusi Press, 2006)

Jimly Asshiddiqie, Negara Hukum Indonesia: Paradigma Penyelenggaraan Negara Dan Pembangunan Nasional Berwawasan Hukum, Makalah disampaikan pada Pertemuan Nasional Ormas-Ormas Kristen di Jakarta, 10 November 2005,

Jimly Asshiddiqie. Perihal Undang-Undang. Jakarta : Konstitusi Press. 2005.

Jimly Asshidiqie, Model-Model Pengujian Konstitusional di Berbagai Negara, (Jakarta: Konstitusi Press, 2005).

Jimly Assyiddiqie, Pokok-Pokok Hukum Tata Negara Indonesia Pasca Reformasi, (PT.Bhuana Ilmu Populer, Jakarta 2007),

Laica Marzuki, 2009. "Prinsip-Prinsip Pembentukan Peraturan Daerah”, Jurnal Konstitusi MKRI, Vol. 6 Nomor 4, November 2009

Luthfi Widagdo Eddyono, "Penyelesaian Sengketa Kewenangan Lembaga Negara oleh Mahkamah Konstitusi Republik Indonesia", Jurnal Konstitusi, Vol. 7 No.3 Juni 2010

M.Sapta Murti, "Harmonisasi Peraturan Daerah dengan Peraturan Perundang-Undangan Lainnya", Jurnal Legislasi Daerah Edisi II, Mei-Agustus 2010

Macmud Aziz, "Pengujian Peraturan Perundang-undangan dalam sistem Peraturan Prundang-undangan Indonesia", Jurnal Konstitusi, Volume 7 Nomor 5, Oktober 2010

Mahfud, MD.Dasar dan Struktur Ketatanegaraan Indonesia. Jakarta : PT.Rineka Cipta,

Maria Farida Indriati Soeprapto. Ilmu Perundang-Undangan, Dasar-Dasar Dan Pembentukannya. Yogyakarta : Kanisius, 1998.

Maria Farida Indriarti S, 2010. "kedudukan Peraturan Daerah dalam sistem Hukum di Negara republik Indonesia", Jurnal Legislasi daerah, DPRD’ Provinsi jatim, Edisi II Tahun 2010

Montesquieu, The Spirit of Laws, Dasar-Dasar Ilmu Hukum dan Ilmu Politik, diterjemahkan oleh M. Khoiril Anam, (Bandung: Nusamedia, 2007).

Munir Fuady, 2010, Konsep Negara Demokrasi,Refika aditama, Bandung.

Murphy,Mark C., 2007. Philosophy of Law, The Fundamentals. Australia: Blackwell Publishing

Ni'matul huda 2008. "Problematika Yuridis Di Seputar Pembatalan Perda", Jurnal Konstitusi, Vol. 5, Nomor 1, Juni 2008

Ni’matul Huda, Hukum Pemerintahan Daerah, (Bandung: Nusa Media, 2009).

P. Rosodjatmiko, Pemerintahan di Daerah Dan Pelaksanaanya, (Tarsito Bandung, Tarsito, 1982),

Prakosa, Djoko. Proses Pembentukan Daerah dan Beberapa Usaha Penyempurnaannya. (Jakarta : Ghalia Indonesia, 2005).

Pusat Studi Konstitusi Andalas, "Perkembangan Pengujian Perundang-undangan di Mahkamah Konstitusi”, Jurnal Konstitusi, Vil.7 No.6 Desember 2010

Romi, "Kajian Terhadap Prinsip Keadilan Dalam Pemungutan Pajak di Indonesia" Jurnal Media Hukum, Vol. 16 No. 2 Desember 2009

Siswanto Sunarno, Hukum Pemerintahan Daerah Di Indonesia, (Jakarta : Sinar Grafika, 2006).

Siti Fatimah, Praktik Judicial Review di Indonesia: Sebuah Pengantar, (Yogyakarta: Pilar Media. 2005)

Slamet Suhartono, “ Norma Samar (Vage Normen) sebagai Dasar Hukum Pengambilan Keputusan Tata Usaha 
Negara", Jurnal Yustisia FH Universitas Sebelas Maret Surakarta, Edisi Nomor 79, Januari- April 2010

Umbu Lily Pekuwati,"Eksistensi Perda dalam Mewujudkan Kesejaterahan Masyarakat", Jurnal Yustisia FH Universitas Sebelas Maret Surakarta, Edisi Nomor 79, Juanuari-April 2010

Usman FH, "Urgensi Program Legislasi daerah Dalam Pembentukan Peraturan Perundang-undangan daerah Edisi III, September-Desember 2010

W.Friedman, 1993.Teori \&Filsafat hukum: Telaah Kritis Atas Teori-Teori hukum (Susunan I), Judul Asli: Legal Theory, Penerjemah: Mohamad Arifin, Cetakan Ke-dua, Jakarta: PT Grafondo Persada

Widodo Ekathahjana, Pengujian Peraturan Perundang-Undangan Dan Sistem Peradilannya di Indonesia, Pustaka Sutra, Jakarta, 2008

Wirjono Prodjodikoro, Azas-Azas Hukum Tata Negara di Indonesia,( Jakarta Timur: Dian Rakjat, 1983) 